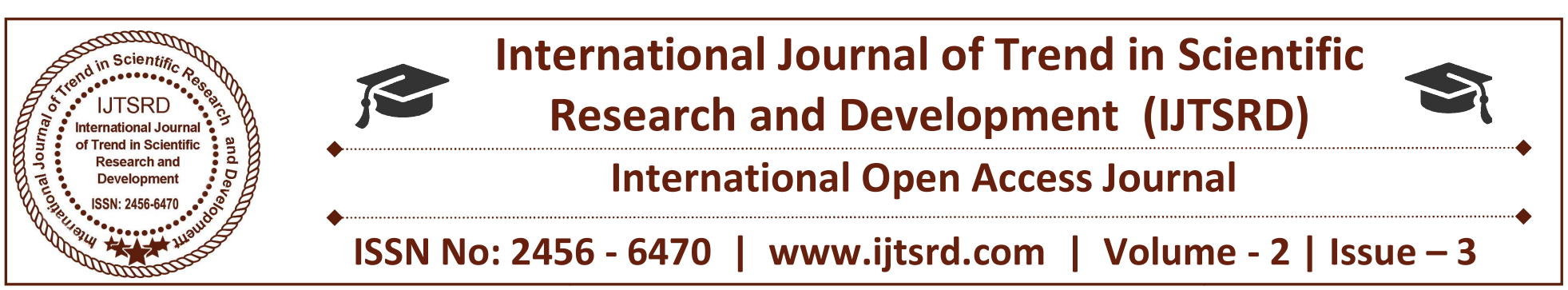

\title{
Corporate Leadership: A Review of Conventional Theories of Leadership
}

\author{
Prof. Dr. Satya Subrahmanyam \\ Head and Managing Partner, Vignan Institute of Technology and Management, \\ Berhampur, Odisha, India
}

\begin{abstract}
This research article was motivated by the premise that no corporate grows further without effective corporate leaders. The purpose of this theoretical debate is to examine the wider context of corporate leadership theories and its effectiveness towards improving corporate leadership in the corporate world. Evolution of corporate leadership theories is a comprehensive study of leadership trends over the years and in various contexts and theoretical foundations. This research article presents the history of dominant corporate leadership theories and research, beginning with Great Man thesis and Trait theory to Decision process theory to various leadership characteristics. This article also offers a convenient way to utilize theoretical knowledge to the practical corporate situation.
\end{abstract}

Keywords: Traits Theory, Behavioural Theory, Contingency Theory, Path Goal Theory, Decision Process Theory

\section{INTRODUCTION}

In the 21 century, business managers are described as corporate leaders and not necessarily managers, even though the word manger is generally in the title of their position. The corporate leaders in many corporate define success as more revenue, more profits, higher market share, cost savings and new product offerings. However, these cannot solely define success. Malcolm Forbes expressed that only a handful of corporate understand that all successful business operations come down to three basic principles: people, product, profit. As it is cited in

Cashman (2008) without top people, one cannot do much with the others. It has been recognized that the top ten percent of corporate leaders show the most positive impact on the business results of a corporate (Zenger \& Folkman, 2003).

Many scholars and researchers have tried to establish a definition of leadership that encompasses the intricacy of this universal term. One simplified definition of leadership is the process of influencing an organized group towards accomplishing its goals. This definition emphasizes the importance of viewing leadership as a process, directed at influencing a specific group of people to meet a stated objective.

Proctor (2004), stated that some leaders are born and others are made. The born leaders innately have many of the necessary characteristics to be a leader and somewhere along the way developed the desire to be leaders. According to this, without the willingness to lead, ability counts for very little. Leaders that are made, according to Proctor, may have some skills but need to develop others through perseverance, practice and consistent application. For these types of aspiring leaders it takes effort and time. Proctor feels that most of us have the ability to develop leadership skills, fewer of us have the desire and therefore the key is willingness (Proctor, 2004).

In his landmark 1978 study on leadership, Burns stated that corporate leadership is one of the most observed and least understood phenomena on earth (Burns, 1978). In the mid 1980s, Bennis stated that never have so many labored so long to say so little and corporate leadership is the most studied and least 
understood topic of any in the social sciences (Bennis \& Nanus, 1985).

To most people, the importance of corporate leadership is self evident no matter what the exact definition or setting. In corporate, effective leadership provides higher quality and more efficient goods and services; it provides a sense of cohesiveness, personal development and higher levels of satisfaction among those conducting the work; and it provides an overarching sense of direction and vision, an alignment with the environment, a healthy mechanism for innovation and creativity and a resource for invigorating the corporate culture (Van Wart, 2003). All of these are valid points; however, the history of corporate leadership theory and research and its utilization in current settings, in relation to the effectiveness of corporate leadership is studied more thoroughly in this article.

\section{REVIEW OF LITERATURE}

Leadership and its study have roots in the beginning of civilization. Interest in leadership theories can be inferred from writings of early civilizations. Confucius (circa 500 B.C) wrote one of the earliest comprehensive treatises on leadership (Ayman, 1993) and discussion of leadership can be found in the writings of Plato, Plutarch and Caesar (Bass, 1981). Egyptian rulers, Greek heroes and biblical patriarchs all have one thing is common - leadership. There are numerous definitions and theories of leadership; however, there are enough similarities in the definitions to conclude that leadership is an effort of influence and the power to induce compliance (Wren, 1994).

The corporate focus of the leader has evolved over this same period. Early corporate with authoritarian leaders who believed employees were basically lazy transitioned into way to make work environments more conductive into increased productivity rates. Today, corporate are transforming into places where people are empowered, encouraged and supported in their personal and professional growth throughout their careers. As the focus of leaders has changed over time, it has influenced and shaped the development and progression of leadership theory.

In more recent times, leadership has continued to be a topic of interest, as well as a subject of contention among many leadership theorists. Several different schools of thought regarding leadership have prevailed simultaneously since early observations in this area of interest began (Stogdill, 1974). Most early theorists presented their findings based on information gained through empirical observation as opposed to statistical research.

Research on leadership theory has evolved (Day \& Antonakis, 2012) and can be divided into four overlapping stages: the trait approach, the behavioral approach, the contingency approach and the new leadership approach. Although advances and contributions to leadership knowledge have been made by researchers, no single approach has been proven as the best way to measure and explain leadership.

\section{GREAT MAN THEORY}

The great man theory of leadership attempted to explain leadership on the basis of heredity. The underlying concept of the theory is that the leader is genetically endowed with super qualities that differentiate him from his followers (Dowd, 1936). In the early years of the $20^{\text {th }}$ century, several leadership theorists were influenced by Galton's (1869) study of the hereditary background of great men. He proposed that great leaders inherit their ability to lead.

In 1931, Wiggam proposed a method by which superior leaders could be maintained in ample quality. He calculated that an adequate supply of leaders depended upon a high birth rate among the biologically superior aristocratic classes. Dowd (1936) claimed that leaders are always more intelligent, energetic and superior than their followers. In 1960, Jennings published a comprehensive survey of the great man theory of leadership. He argued that if the leader is endowed with superior qualities then it should be possible to identify these qualities. This search for measurable qualities became the underlying concept of the trait theories of leadership.

\section{THE TRAIT THEORY}

The trait theory was the prevalent workplace philosophy in the preindustrial age $(1800-1900)$. The theory arose in an environment where mercantile and agricultural workers possessed minimal educational and limited technical expertise. Trait theories asserted that all leaders shared similar personal characteristics and that leaders were born not made. Leader trait research included exploration of the physical, mental and social characteristics of individuals, looking for association between traits and leadership effectiveness (Barnett, 2012). 
The five factor model of personality developed later is known as the big five theory and represents five core traits forming a personality - extroversion, agreeableness, conscientiousness, neuroticism and openness (Costa \& McCrae, 1992). Extroversion and neuroticism are considered personality manifestations of sensitivity to reward and threat; conscientiousness reflects the tendency to exert control of behavior and follow rules; agreeableness reflects altruism and cooperation; openness and intellect reflect the tendency to explore and use sensory information (De Young, 2010).

Germinal trait theorists, such as Stogdill (1948), identified personality attributes that differentiate leaders from followers. The attributes include a) achievement drive referring to high levels of energy, ambition and initiative; b) leadership motivation referring to intense desire to reach goals; integrity referring to trustworthiness and reliability and c) selfconfidence. Stogdill (1974) reviewed numerous trait studies and concluded that individual traits depend on the situation with no evidence of the existence of universal leadership traits. Stogdill (1974) further reported a leader's use of specific traits and skills does not ensure effectiveness.

Early trait research excluded the effect of situational variables moderating the relationship between leader effectiveness and traits. The trait approach emphasized naturally endowed leadership traits that include inherited, genetic predisposition of characteristics predictive of individuals' attaining leadership positions (Bass 1990; Kirkpatrick \& Locke, 1991). Skills refer to effectiveness in accomplishing tasks. New trait theory identified more than 1400 characteristics depicting how a leader's traits relate to leadership behavior and how effectiveness related to managerial motivation and specific skills (Bass, 2002).

In recent research, emphasis is on the link between generics and creativity, specifically in the area of neuroplasticity (i.e., regulatory process of brain synaptic pruning) associated with creativity because the brain generates new neural pathways for the purpose of efficiency. The brain experiences the world through the senses and learning from experiences occurs; new neural pathways support creativity, enabling people to use more of their brain and stimulating divergent thinking through more sensory learning (Kuszewski, 2009).

\section{THE BEHAVIOURAL THEORY}

The modernist philosophy of workplace values prevalent in the industrial age $(1910-1980)$ arose from an environment in which industrial workers were considered a cost (Drucker, 2006). Industrial workers valued mass production and profits and created specialized jobs to increase production. In 1966, McGregor introduced leadership theories X and $\mathrm{Y}$, defining the authoritative leadership style as $\mathrm{X}$ and the participative as $\mathrm{Y}$. The authoritative style is characterized by production - oriented tight control of worker activities and decisions by the leader. In the later years of industrial age, the participative style emerged that emphasized worker - focused democratic decision making. Many researchers became disappointed with the earlier trait approach in explaining leadership success (Stogdill, 1974) and considered the behavioral approach in the early 1950s. The behavioral theory downplayed a leader's natural traits and advocated behaviors as a means to lead effectively through emphasizing actions rather than personal characteristics. In the 1940s and 1950s, researchers at the University of Michigan and Ohio State University produced two germinal, behavioral leadership studies. Researchers at Ohio State University identified two categories of leadership behavior - a) concern for task and b) concern for people. The focus of the concern for task is on accomplishing the assigned task and giving importance to such things as meeting deadlines and performance standards. The focus of the concern for people was on the needs and feelings of subordinates and included such behaviors as accepting suggestions from subordinates and treating them as equals.

A major challenge for early researchers was to determine meaningful and relevant behaviors, so they developed various taxonomies of behaviors or functions. In an earlier study Mintzberg (1973) observed the content of managerial activities and developed a taxonomy of managerial roles that fall in three behavioral categories - a) interpersonal ( i.e., liaison, figurehead and leader, b) information processing behavior (i.e., monitor discriminator and spokesperson) and c) decision - making behavior (i.e., entrepreneur, disturbance handler, resource allocator and negotiator). The roles depicted the action oriented nature of leadership rather than innate traits. Different forms of leadership are most effective in 
different situational contexts including the nature of the work, follower's characteristics and the nature of the external environment (Clawson, 2006).

Task Behaviors: Three essential behaviors paramount to effective leadership include clarifying roles and goals, short - term planning and monitoring performance (Yukl, 2010). Short - term planning involves effective utilization of resources and coordination of activities. Evidence exists of a relationship between planning and leadership activities. Clarifying communications between leaders and followers is needed to guide work activity and a relationship exists between communication skills and leadership effectiveness (Hersey \& Blanchard, 1988).

Relations Behaviors: The following five specific relations - oriented behaviors are relevant for effective leadership - a) team building, b) consulting and delegating, c) supporting, d) developing and e) recognizing. Team building involves shared commitment toward common goals and high levels of cooperation and trust that yield high performance (Bass, Avolio \& Jung, 1999; Yukl, Gordon \& Tabor, 2002). Consulting and delegating involves asking others for their opinions and delegating to individuals or groups the authority and responsibility for decision making. Supporting involves showing concern for the needs of others. Supportive leadership builds effective relationships making it easier to gain support and cooperation (Van Vugt \& De Cramer, 1999).

Developing employees involves skill building and fostering mutually cooperative relations leading to higher employee commitment and higher performance and recognizing involves giving praise for work accomplishments; effective leaders show appreciation to subordinates for their contributions and achievements (Soriano \& Martinez, 2007). In the three - dimensional leadership behavior theory (change, task and relation - orientation) the relation orientated leadership behavior was the strongest factor often used as the base although task and change orientation can be applied according to the situation (Parker, 2008).

Change Behaviors: Successful leadership execution of change has been identified as leading to innovation (Gilley et al., 2008). Leadership execution includes leadership abilities that drive innovation such as coaching, rewarding, communicating with an array of techniques, motivating, empowering and promoting collaborative team work. Such abilities support past research linking specific skills, leadership effectiveness, managing change and understanding the complex dynamics inherent in the innovation process (Gilley et al., 2008).

(From 1950 until about 1980s, leadership research became interested in the behavioral school of leadership. Contingency theories describe how aspects of the leadership situation modify a leader's influence on an individual (Bryman et al., 2011).

The independent variables in most contingency theories are leadership behavior. This interest in the behavioral approach is characterized by efforts to identify leadership styles and to identify the best combination of leadership behaviors (Kerr, Schriesheim, Murphy \& Stogdill, 1974). The Universities of Michigan, Harvard and Ohio were leading centers of work in this approach.

The Michigan Studies headed by Likert, focused a study on differences between high producing and poor producing managers. He observed that high producing managers have the following traits: workers measuring their own performance using selfguidance, workers having positive attitudes towards their jobs and making use of all the available technical resources (Likert, 1961).

In these high performing organizations, workers tended to be highly motivated, because works were treated as human beings and managers tried to view things through their employee's eyes and thereby valuing their personal worth and developing supportive relationships with workers. Likert (1961) favored group decision making and viewed the use of work groups as essential.

Likert (1961) also identified a connection between levels of management where a superior's decisions could only be affected if the superior has sufficient influence with his own superior. To be effective, a supervisor must exert influence up in the organization. The higher one goes in an organization the more important this linking process becomes.

Most contingency theories of effective leadership use broadly defined categories of behavior. These two broad classes of leader behaviors include task oriented behavior, relationships oriented behavior, participative leadership and contingent reward behavior (Bryman et al., 2011) 
Task oriented behavior is primarily concerned with accomplishing tasks in an efficient manner by following the company rules and regulations. Common labels for this meta-category include initiating structure, instrumental leadership and directive leadership. The specific component behaviors vary depending on the theory and measure. The degree of two way communication and consultation, warmth, respect and mutual trust a leader displays toward his followers $\mathrm{s}$ embedded in consideration and involves a real concern for subordinates as people. Initiating structure refer to the degree which a leader defines communication channels, organizes group activities and methods of accomplishing work (Bryman et al., 2011).

During the development of the Ohio State concepts, Korman (1966) found that researchers had not paid enough attention to the chances that leader effectiveness may be situational contingent. This means that in some contexts, leader behavior may be effective and ineffective in others.)

\section{THE CONTINGENCY THEORY}

As a result of the problem identified with the behavioral approach, the next wave of leadership research, known as the contingency approach-slate 1960 s to 1980 s arose, which gave priority to situational factors.

Five important theoretical viewpoints were included in this approach and are summarized...

* Fielder's contingency theory of leadership (Fielder, 1967; 1991)

* Path-Goal theory of leader effectiveness (House, 1971)

* Hersey and Blanchard's life cycle theory (1969)

* Cognitive resource theory (Fielder \& Garcia, 1987)

* Decision process theory (Vroom \& Yetton, 1973)

\section{FIELDER'S CONTINGENCY THEORY OF LEADERSHIP}

In the 1960s, Fiedler developed contingency theory because the previous theories did not take into account situational context on leadership performance (McMahon, 1972; Jago, 1982). Fielder and Chemers stated that contingency theory was a leader-match theory, which means it tries to match leaders to appropriate situations (as cited in Browning, 2007).

The main tenet of contingency theory is to find a situation to fit a leader's style. Effective leadership is contingent on matching a leader's style to the right setting (Northouse, 2007). The effectiveness of the group is linked to the style, or motivational disposition of the leader (Miller, Butler \& Cosentino, 2004). Motivational disposition is the degree of task or relationship orientation of the leader. A taskoriented disposition is most interested in meeting a goal and a relationship motivated disposition is mot focused on developing interpersonal relationships.

One key aspect of contingency theory, unlike the other theories is that it is a predictive theory. The fact contingency is grounded in empirical research is a strength. Contingency theory does not mandate that all leaders are effective in all situations. Contingency theory challenged the one-best-way theory to leadership and provided a valuable first step toward conceptualizing leadership in terms of situational dependencies (Jago, 1982).

Contingency theory is widely considered a personality theory, due to its basis in applied trait theory. Proponents of contingency theory recommend using situational engineering to change the situation to fit the leader. Contingency theory does not advocate changing the leader to fit the situation. In a business setting, contingency theory may help provide guidance to structure situations to ensure maximum fit for the leader in different circumstances. Fielder and Chemers created leader match, an organizational training program to match the leadership style with the situation to provide optimal leadership effectiveness (as cited in Jago \& Ragan, 1986).

\section{HERSEY AND BLANCHARD'S SITUATIONAL LEADERSHIP MODEL (SLM)}

Blank, Weitzel and Green (1990) explained situational leadership theory focused on two primary types of leaders, leaders focused on task behaviors and leaders focused on relationship behaviors. Hersey and Blanchard (1973) contended behaviors were similar to the consideration and initiation of structure well grounded in leadership literature. Task and relationship behaviors are operationalized in a manner that closely parallels existing operationalizations of consideration and initiation of structure.

Blank et al. (1990) stated the focus of situational leadership theory was subordinate maturity as the key situational characteristic bonding the relationship between leader behaviors in tasks and relationships and leader effectiveness. Subordinates' maturity levels in the work relationship are the ability and willingness of employees to take responsibility for 
directing their own behavior (Hersey \& Blanchard, 1973).

According to Blank et al. (1990), Hersey and Blanchard argued that subordinate maturity consists of two dimensions - psychological maturity and job maturity. Psychological maturity was defined in Hersey and Blanchard's (1973) recent work as a willingness or motivation to do something and as having to do with confidence and commitment. In earlier works, psychological maturity was defined in terms of subordinates' relative independence, achievement motivation and ability to take responsibility. Hersey and Blanchard believed the relative independence component derived from an individual's self-sufficiency. Job maturity is defined in terms of the ability to do something (Hersey \& Blanchard, 1973) and is seen as strongly related to educational and job experience.

A premise of situational leadership theory is that leader effectiveness results from appropriate amounts of task and relationship behaviors provided for subordinates at different levels of maturity (Hersey \& Blanchard, 1973). There is a liner relationship between subordinates' psychological and job maturity and task behavior. Hersey and Blanchard claimed leadership styles should be matched to subordinates' maturity level. The assessment of maturity in relation to a specific task is based on a) psychological maturity or self-confidence, ability and readiness to accept responsibility and b) job maturity or relevant skills and technical knowledge.

As subordinates' maturity increases, leaders should become more relationship oriented than task oriented. The following are four levels of maturity in leadership style, ranging from mature to immature - a) delegating to subordinates, b) participating with subordinates, c) selling ideas to subordinates and d) telling subordinates what to do (Vecchio, 1988). When the maturity levels of subordinates are low, leaders must provide high amounts of task behavior. When the subordinates' maturity is high leaders should provide low amounts of task behavior. The relationship between subordinate maturity and relationship behavior is complex and curvilinear. Hersey and Blanchard (1973) characterized leadership style in terms of the amount of direction and support leaders their followers and created a simple grid. In the grid, directing leaders define the roles and tasks of followers and supervise followers closely. Directing leaders make and announce decisions through oneway communication primarily.

Coaching leaders define roles and tasks but seek ideas and suggestions from followers. Decisions remain the leaders' prerogative, but communication tends to be two way. Supporting leaders make day-to-day decisions such as task allocation and processes to followers. The leaders facilitate and take part in decisions, but followers have control (Vecchio, 1988). Delegating leaders are involved in decisions and problem solving, but followers have control. The followers decide when and how the leaders will be involved. Effective leaders are versatile and able to move around the grid according to the situation, using several styles. Managers tend to have a preferred leadership style. In applying situational leadership, manages must understand which leadership style works best (Blank et al, 1990).

\section{THE PATH-GOAL THEORY OF LEADER EFFECTIVENESS}

According to Northouse (2007) and Yukl (2006), path-goal theory is supported by comprehensive research dealing with what motivates employees. Path-goal theory examines how leaders motivate employees to achieve goals. The goal of this theory is to improve employee's performance and satisfaction by focusing on employee motivation. Path-goal theory emphasizes the relationship between the leader's style and the characteristics of the subordinates and the work setting.

Northouse (2007) and Yukl (2006), all stated pathgoal theory provides four leadership styles - directive, supportive, participative and achievement-oriented. The causal variable for path-goal theory of leadership is leader behavior. The intervening variables are subordinate expectations and valences. Situational moderator variables include characteristics of task and environment and the characteristic of subordinates. Causal relationships of effectives of supportive leadership on subordinates are reducing boredom and making the job more tolerable; increasing the intrinsic valence of work; increasing self-confidence and lowering anxiety; increasing the intrinsic valence of work; increasing self-confidence and lowering anxiety and increasing effort-performance expectancy, which all results in increased effort. Causal relationships for effects of directive leadership on subordinates include reduced role ambiguity and increasing the effortperformance expectancy, increased size of incentive followed by increasing outcome valences for task 
success and strengthening required contingencies followed by increasing performance-reward expectancies with all three avenues resulting in increased subordinate effort.

\section{THE COGNITIVE RESOURCE THEORY}

Fielder continued working on his leadership approach using the least-preferred-co-worker (LPC) scale, even though there was criticism against it. This led to the development of the cognitive resource theory (CRT), which used the personal variables of the experience and intelligence of the leader and the situational variables stress (Fielder \& Garcia, 1987). The realization was that when the stress is low, there is a positive relationship between performance and intelligence and a negative relationship between experience and performance (Bryman et at., 2011). Under conditions of high stress, the opposite was true and there is a negative relationship between performance and intelligence, with a positive relationship between experience and performance.

The conclusion, according to House and Aditya (1997) is that intelligence and experience interfere with each other. Bryman et al., (2011) suggest that business should select and employ people who possess the intelligence, experience and knowledge to achieve leadership that is effective. Thereafter, these leadership attributes should be enabled for the leaders then to make use of their cognitive resources that they possess and work under conditions that allow them to use these resources. Another crucial factor is the stress experience and the leader being in control of the situation.

\section{THE DECISION PROCESS THEORY}

The Decision Process Theory developed by Vroom and Yetton (1973) is the final situational leadership theory, which was extended by Vroom and Jago (1988). The foundation of the approach is to aid managers in the process of making difficult technical or economic decisions. In the original model, Vroom and Yetton (1973) describe five decision-making processes, which could be followed to determine the amount and type of leader participation depending on seven contingencies. The model is in the format of a decision tree, with branches that apply rules particular to the specific situation (Vroom \& Yetton, 1973). Ti is based on sequential questions concerning the problem. The questions address quality requirements, sufficient information, problem structure, acceptance by subordinates, goals of subordinates and conflict among subordinates.

According to House and Aditya (1997), there has been a greater support from filed studies than laboratory studies overall. The disapprovals include the supposition that the leader's objectives are always compatible with those of the organization, lack of interest in discussion skills that the leader requires for group problem solving and the theory that is markedly multifarious (Field, 1979).

When revising the model, Vroom and Jago (1988) added five situational factors, as well as making changes to the provision of the key variables and the manner of presenting the model prescriptions was also made by Vroom (2000). Even though the original model was updated over time, the Vroom, Yetton and Jago research shows the importance of taking the situation into account (Vroom \& Jago, 2007). Vroom and Jago (2007) are further of the opinion that their research underscores the significant role of situational forces guiding actions and based their opinion on organizational effectiveness and how situations shape and influence the behavior and consequences of leader behavior.

However, by the end of the 1980 s interest in the contingency approaches has waned due to researches becoming disenchanted when they found inconsistent results in their studies using the various theories (Bryman et al., 2011). In a continuous search for explanations on how leaders could improve on the results in their business evidently led to new developments in leadership theories.

\section{Concluding Remarks}

More frequently, academic commentaries and books surface that blends theoretical, empirical and practical ideas and knowledge relevant to understanding studies, methodologies and issues essential to corporate leadership. These syntheses are only achieved with the reflective ability of the corporate leaders to link thematic issues across wider range and overlapping themes from which they start off and become known.

To this end, this article has discussed effective corporate leadership and a quality wake up call for a better theory that has applicability to a particular corporate situation. By examining the circumstances surrounding effective corporate leadership, this article could conclude that success is certain if the application of the appropriate leadership theory properly and fully applied. The tradition of corporate 
leadership offers great opportunity to further refine corporate leadership practices by accepting and utilizing the basic leadership theories.

Corporate leaders know that leadership requires a number of judgements each day that requires sensitivity and understanding of various leadership strategies. Thus, bridging the gap between theory and practice should be able to provide exploration of dominant leadership strategies to corporate leaders a solid basis in theory and practical application. Corporate leaders are encouraged to discover the most appropriate leadership theory or combinations of theories that will best enable the corporate achieve results.

\section{REFERENCES}

1. Ayman, R., 1993. Leadership perceptions: The role of gender and culture. In M.M. Chemers, \& R. Ayman (Eds.), Leadership Theory and Research: Perspectives and directions, 49-88, San Diego, CA: Academic Press.

2. Barnett, T., 2012. Leadership Theories and Studies. Retrieved from http://www. referenceforbusiness.com/management/IntLoc/Leadership-Theories-and Studies.html.

3. Bass, B., 1981. Stodgill's Handbook of Leadership: A survey of theory and research $\left(2^{\text {nd }}\right.$ ed.), New York, Free Press.

4. Bass, B.M., 1990. Bass \& Stogdill's Handbook of Leadership: Theory, research, and managerial applications (3rd ed.), New York, The Free Press.

5. Bass, B. M., 2002. Forecasting organizational leadership: From back (1962) to the future (2034). In B. J. Avolio \& F. J. Yammarino (Eds.), Transformational and charismatic leadership: The road ahead, 375-384, Oxford, UK: Elsevier.

6. Bennis., W.G., \& Nanus, B., 1985. Leaders: The strategies for taking charge. New York, NY: Harper \& Row.

7. Blank, W., Weitzel, J. R., \& Green, S. G., 1990. A test of the situational leadership theory. Personnel Psychology, 43, 579-597. Retrieved from Proquest database.

8. Browning, B., 2007. Leadership in desperate times: An analysis of endurance: Shackleton's incredible voyage through the lens of leadership theory. Advances in Developing Human Resources, 9(2), 183-198.

9. Bryman, A. \& Bell, E.,2011. Business Research Methods. Oxford: Oxford University.
10. Burns, J.M., 1978. Leadership. New York, Harper \& Row Publishers.

11. Clawson, J. G., 2006. Level Three Leadership: Getting below the surface $\left(3^{\text {rd }}\right.$ ed.), New York, NY: Pearson.

12. Costa, P. T., Jr., \& McCrae, R. R., 1992. Revised NEO personality inventory and NEO five-factor inventory manual. Odessa, FL: Psychological Assessment Resources.

13. Day, D. V., \& Antonakis, J. (Eds.)., 2012. The Nature of Leadership ( $2^{\text {nd }}$ ed.), London, UK: Sage.

14. DeYoung, C. G., 2010. Toward a theory of the big five. Psychological Inquiry, 21, 26-33. doi:10.1080/10478401003648674.

15. Dowd, J., 1936. Control in Human Societies. New York: Appleton-Century.

16. Drucker, P., 1992. The new society of organizations. Harvard Business Review. September-October, 95-104. Retrieved from https://hbr.org/my-library.

17. Fiedler, F.E. \& Garcia, J.E., 1987. New Approaches to Leadership: Cognitive resources and organisational performance. NY: Wiley.

18. Galton, F., 1869. Hereditary Genius: An inquiry into its laws and consequences. London: Macmillan.

19. Gilley, A., Dixon, P., \& Gilley, J. W., 2008. Characteristics of leadership effectiveness: Implementing change and driving innovation in organizations. Human Resource Development Quarterly, 19, 153-169. doi:10.1002/hrdq.1232

20. Hersey, P. \& Blanchard, K.H., 1988. Management of Organizational Behaviour: Utilizing human resources. Englewood Cliffs, NJ: Prentice-Hall.

21. House, R.J. \& Aditya, R.N., 1997. The social scientific study of leadership: Quo vadis? Journal of Management, 23(3), 409-473.

22. Jago, A.G., 1982. Leadership: Perspectives in theory and research. Management Science, 28(3), 315-336.

23. Jago, A.G., \& Ragan, J., 1986. The trouble with \{leader match\} is that it doesn't match Fiedler's contingency model. Journal of Applied Psychology, 71(4), 555-559. doi:10.1037/00219010.71.4.555

24. Jennings, E.E., 1960. An Anatomy of Leadership: princes, heroes, and supermen. New York: Harper.

25. Kerr, S., Schriesheim, C., Murphy, C., \& Stogdill, R., 1974. Toward a contingency theory of 
leadership based upon the consideration and initiating structure literature. Organizational Behavior and Human Performance, 12, 62-82. doi:10.1016/0030-5073(74)90037-3.

26. Korman, A.K., 1966. Consideration, Initiating Structure and Organisational Criteria - a review. Personnel Psychology, 19(4), 349-361.

27. Kirkpatrick, S. A., \& Locke, E. A., 1991. Leadership: Do traits matter?. Academy of Management Executives, 5, 48-60. Retrieved from http://aom.org/journals.

28. Kuszewski, A., 2009. The genetics of creativity: A serendipitous assemblage of madness. Metodo Working Papers, 58. Retrieved from http://papers.ssrn.com/ sol3/papers.cfm?abstract_id $=1393603$

29. Likert, R., 1961. New Patterns of Management. New York, NY: McGraw-Hill.

30. McMahon, J., 1972. The contingency theory: Logic and method revisited. Personnel Psychology, 25(4), 697-710.

31. Miller, R., Butler, J., \& Cosentino, C., 2004. Followership effectiveness: an extension of Fiedler's contingency model. Leadership \& Organization Development Journal, 25(3/4), 362368.

32. Mintzberg, H., 1973. The Nature of Managerial Work. New York, NY: Harper \& Row.

33. Northouse, P. G., 2007. Leadership: Theory and practice (3rd ed.). Thousand Oaks, CA: Sage.

34. Parker, G., 2008. Team players and teamwork: New strategies for developing successful collaboration, completely updated and revised. San Francisco, CA: Jossey-Bass.

35. Proctor, G., 2004. Responding to injustice: working with angry and violent clients in a person-centred way. In Working with Dangerous People: The psychotherapy of violence. (Ed. D. Jones) Oxford: Radcliffe Medical Press.

36. Soriano, D. R., \& Martinez, M. C., 2007. Transmitting the entrepreneurial spirit to the work team in SMEs: The importance of leadership. Management Decision, 45, 1102-1122. doi:10.1108/00251740710773934.

37. Stogdill, R. M., 1948. Personal factors associated with leadership; a survey of the literature. Journal of Psychology, 25, 35-71.

38. Stogdill, R.M., 1974. Handbook of leadership: A survey of theory and research. New York: Free Press.

39. VanVugt, M., \& De Cramer, D., 1999. Leadership in social dilemmas: The effects of group identification on collective actions to provide public goods. Journal of Personality and Social Psychology, 76, 587-599. Retrieved from http://www.apa.org/pubs/journals/psp/index.aspx

40. Van Wart, M., 2004. A comprehensive model of organizational leadership: The leadership action model. International Journal of Organizational theory and behavior, 7(2), 173-289. Retrieved from ProQuest database.

41. Vecchio, R. P., 1988. Organizational Behavior. New York: Dryden Press.

42. Vroom, V. H., 2000. Leadership and decision making process. Organizational Dynamics, 28(4), 82-94. doi:10.1016/S0090-2616(00)00003-6

43. Vroom, V. H., \& Jago, A. G., 1988. The New Leadership: Managing participation in organizations. Englewood Cliffs, NJ: Prentice Hall.

44. Vroom, V.H., \& Yetton, P.W., 1973. Leadership and Decision-making. Pittsburg, Pennsylvania: University of Pittsburg Press.

45. Wiggam, A.E., 1931. The biology of leadership. In H.C. Metcalf (Ed.), Business leadership. New York: Pitman.

46. Wren, D. A., 1994. The Evolution of Management Thought. Hoboken, NJ: Wiley Publishers.

47. Yukl, G., 2010. Leadership in Organizations, $\left(7^{\text {th }}\right.$ ed.). New Jersey: Prentice Hall.

48. Yukl, G., Gordon, A., \& Taber, T., 2002. A hierarchical taxonomy of leadership behavior: Integrating a half century of behaviour research. Journal of Leadership and Organizational Studies, 9(1), 15-32.

49. Zenger,J.H. \& Folkman, J., 2003. Developing leaders, Executive Excellence, 20(9), 5. 